\title{
Manajemen Asuhan Kebidanan Gangguan Sistem Reproduksi pada Ny "S" dengan Mioma Submukosa di RSUD Syekh Yusuf Gowa Tanggal 04 Februari - 25 Februari Tahun 2019
}

\author{
${ }^{1}$ Astuti, ${ }^{2}$ Anieq Mumthi'ah Al Kautzar, ${ }^{3}$ Darmawansyih
}

\begin{abstract}
ABSTRAK
Pendahuluan Mioma uteri adalah tumor jinak uterus yang mengandung sel-sel otot polos dan jaringan ikat dengan ciri bulat, keras, berwarna merah muda pucat. Umumnya berlokasi pada korpus uteri.

Metode Jenis penelitian ini adalah studi kasus dengan pendekatan Manajemen Asuhan Kebidanan Gangguan Sistem Reroduksi pada Ny "S" dengan Mioma Submukosa di RSUD Syekh Yusuf Gowa Tahun 2019 sesuai Manejemen Asuhan Kebidanan 7 langkah Varney dan pendokumentasian dalam bentuk SOAP.
\end{abstract}

Hasil Asuhan yang diberikan pada Ny "S" pada kasus mioma submukosa yaitu dilakukan dengan pemberian asuhan yang sesuai standar operasional serta melakukan upaya pencegahan komplikasi terjadinya torsi (putaran tungkai), infeksi, dan keganasan, serta dilakukan pemantauan dan asuhan manajemen kebidanan dilakukan pemantauan selama dua hari sebelum operasi dan tiga hari setelah operasi dan melakukan kunjungan rumah selama tiga kali.

Kesimpulan dari kasus yaitu diantaranya pendokumentasian dalam bentuk SOAP yang digunakan untuk proses penyelesaian masalah kebidanan telah dilaksanakan pengkajian berupa pemantauan dari analisa data pada Ny "S" dengan Mioma Submukosa Di RSUD Syekh Yusuf Gowa Tahun 2019. Yakni dari pengkajian sebelum operasi dan setelah operasi tidak ditemukan komplikasi pada ibu di tandai dengan tandatanda vital normal, dan pengankatan tumor berjalan normal.
*UIN Alauddin Makassar

*astutiabbas3@gmail.com
Kata kunci :

Mioma Submukosa;

7 langkah varney

\section{PENDAHULUAN}

Menurut penelitian World Health Organisation (WHO) setiap tahun jumlah penderita mioma bertambah mencapai 6,25 juta orang dalam 10 tahun mendatang diperkirakan 9 juta orang akan meninggal setiap tahun akibat mioma di dunia akan berada dinegara-negara yang sedang berkembang (Setiati E,2014).

Mioma uteri merupakan tumor jinak terbanyak pada wanita dan merupakan indikasi histerektomi tersering di Amerika serikat. Tercatat sebanyak 39\% dari 600.000 histerektomi yang di lakukan di Amerika Serikat tiap tahunnya. Studi yang dilakukan di Amerika Serikat dengan teknik Rondom sampling pada wanita usia 35-49 tahun menemukan bahwa 60\% kasus terjadi pada usia 35 tahun dan meningkat sebanyak $80 \%$ diusia 50 tahun pada wanita 
Afio-Amerika. Sedangkan pada wanita Kaukasian insiden mioma uteri mencapai $40 \%$ pada usia 35 tahun dan 70\% pada usia 50 tahun (Pasinggi, 2015).

Resiko mioma uteri meningkat seiring dengan peningkatan umur. Penelitian di Italia (2004) melaporkan 73 kasus mioma uteri dari 341 wanita pada usia 30-60 tahun dengan prevalensi 21.4\%. Di india (2006) terdapat 150 kasus mioma uteri, 77 kasus (51\%) terjadi pada wanita usia 40-49 tahun dan 45 kasus (30\%) terjadi pada wanita umur lebih dari 50 tahun. Di Nigeria (2014) melaporkan persoalan kesehatan dari segala aspek lapisan masyarakat dan memiliki jumlah kasus mioma uteri yang cukup tinggi.

Prevalensi mioma uteri sebanyak 44, 41\% pada wanita dengan usia 31-40 tahun denganusia rata-rata terjadi pada wanita usia 30-50 tahun. Di Indonesia mioma uteri ditemukan 2,39\%-11,7\% pada semua penderita ginekologi yang dirawat dan paling sering ditemukan pada wanita umur 35-45 tahun kurang lebih 25\%) serta jarang terjadi pada wanita umur 20 tahun dan pasca menopause (Syahlani Ahmad, 2016).

Berdasarkan otopsi, Novak menemukan 27\% wanita berumur 25 tahun mempunyai sarang mioma, pada wanita yang berkulit hitam ditemukan lebih banyak. Mioma uteri belum pernah (dilaporkan) sebelum menarche. Setelah menopause hanya kira-kira 10\% mioma yang masih bertumbuh. Di Indonesia mioma uteri ditemukan $2.39-11.7 \%$ pada semua penderita ginekologi, penyebab mioma uteri belum diketahui secara pasti sampai saat ini. Tumor ini mungkin berasal dari sel embrional pada dinding pembuluh darah uterus. Apapun asalnya, mioma mulai dari benih-benih multiple yang sangat kecil dan terbesar pada miometrium. Benih ini tumbuh sangat kecil dan tersebar pada miometrium. Benih ini tumbuh sangat lambat tetapi progresif dibawah pengaruh estrogen dan jika terdeteksi dan tidak diobati dapat membentuk tumor dengan berat $10 \mathrm{~kg}$ atau lebih, namun sekarang sudah jarang karena cepat terdeteksi (Yosi Apriani, 2017).

Mioma uteri dapat mengakibatkan permukaan endometrium yang lebih luas daripada biasanya, perdarahan mioma uteri dapat berdampak pada ibu hamil dan penderita mioma uteri itu sendiri. Ibu hamil akan mengalami dampak berupa abortus spontan, persalinan, prematur, dan mal presentasi. Pada penderita mioma uteri akan mengalami perdarahan yang banyak dan dapat mengakibatkan anemia. Perdarahan yang banyak juga dapat terjadi pada pencernaan karena perluasan dan pembesaran mioma uteri sehingga pasien mioma uteri tidak hanya dilakukan operasi pada alat kelamin, tetapi juga dilakukan operasi pencernaan (coloctomy). Pada kasus ini mioma uteri mengalami komplikasi yang berat dan dapat 
memperburuk kesehatan pasien tersebut mengalami penurunan kesehatan karena terjadi gangguan pada nutrisi dan tubuh mengalami kelemahan hingga menjadi syok, dan pada akhirnya menimbulkan kematian (Yosi Apriani, 2017).

Profil Dinas Kesehatan Sulawesi Selatan mencatat angka kejadian mioma uteri pada tahun 2011 sebanyak 149 penderita yaitu umur 5-14 tahun sebanyak 7 penderita 4,69\%), umur 15-24 tahun sebanyak 18 orang, $(12,08 \%)$, umur 22-44 tahun sebanyak 90 penderita (60-40\%), umur 45-64 tahun sebanyak 33 penderita (22,15\%) dan umur 65 tahun keatas sebanyak 1 penderita $(0,067 \%)$ (Depkes, 2014).

Berdasarkan data yang diperoleh dari Rekam Medik Rumah Sakit Umum Daerah Syekh Yusuf Kabupaten Gowa menunjukkan jumlah kejadian mioma uteri dari tahun 2015 yaitu sebanyak 2 kasus, pada tahun 2016 sebanyak 4 kasus dan pada tahun 2017 sebanyak 9 kasus (Rekam Medik RSUD Syekh Yusuf, 2017).

Berdasarkan uraian diatas maka penulis merasa tertarik membahas masalah mioma uteri secara spesifik dengan menggunakan pendekatan Manajemen Asuhan Kebidanan Gangguan Sistem Reproduksi Pada Ny "S” Dengan Mioma Submukosa Di RSUD Syekh Yusuf Gowa Tanggal 04 Februari-25 Februari 2019.

\section{METODE PENELITIAN}

Jenis penelitian ini adalah studi kasus dengan pendekatan Manajemen Asuhan Kebidanan sesuai dengan 7 langkah varney dan pendokumentasian dalam bentuk SOAP. Penatalaksanaa asuhan dilakukan dengan pemberin asuhan yang sesuai standar operasional prosedur pada kasus yang diteliti yaitu Mioma Submukosa pada Ny "S" Di RSUD Syekh Yusuf Gowa

\section{HASIL PENELITIAN}

Penelitian ini dilakukan di RSUD Syekh Yusuf Gowa mulai 04 februari - 25 februari 2019. Banyaknya hal yang harus diperhatikan saat masa perawatan masalah kesehatan reproduksi pada wanita salah satu masalah penyakit gangguan sistem reproduksi pada penyakit tumor sdapat dilakukan perawatan yang tepat akan memperkecil resiko terjadinya kanker. Kenyamanan ibu pada masa perawatan termasuk dalam asuhan sayang ibu yang sangat penting untuk dilakukn oleh Bidan selain itu penanganan yang benar dan memastian semua proses perawatan pada ibu sebelum dan sesudah operasi pengangkatan tumor dalam batas normal akan membantu menurunkan resiko patologi pada ibu sehingga tujuan untuk 
menurunkan angka kesakitan ibu dapat tercapai. Mengingat pentingnya dilakukan asuhan yang tepat pada ibu.

Maka penulis tertarik melakukan tinjauan kasus untuk mengkaji memaparkannya sebagai wujud perhatian dan tanggung jawab pada berbagai pihak terkait tentang "Manajemen Asuhan kebidanan Gangguan Sistem Reproduksi pada Ny "S" Dengan Mioma Submukosa Di RSUD Syekh Yusuf Gowa Tanggal 04 Februari - 25 Februari Tahun 2019”. Melakukan upaya pencegahan komplikasi terjadinya nekrosis (putaran tungkai), infeksi, serta dilakukannya pemantauan dan asuhan Manajemen Kebidanan mulai perawatan sebelum operasi dan setelah operasi.

\section{PEMBAHASAN}

Berdasarkan hasil pengkajian pada kasus $\mathrm{Ny}$ "S" usia 47 tahun didapatkan bahwa ibu masuk pada tanggal 4 februari 2019 pukul 11:30 WITA dengan keluhan nyeri perut bagian bawah disertai pengeluaran darah sejak 1 minggu yang lalu sampai sekarang, selain itu ada kelainan lain yang menyertai ibu pusing pada kepala dan merasa lemas, Ibu mengatakan tidak ada riwayat keturunan.

Bedasarkan studi kasus pada Ny "S" maka data yang diperoleh dari hasil pengkajian atau anamnesa pemeriksaan fisik didapatkan tanda-tanda vital batas normal ekspresi wajah tampak cemas, pucat dan meringis menahan sakit, tidak ada oedema dan pembengkakan pada wajah, konjungtiva mata anemis, tidak ada pembesaran pada kelenjar tiroid, limfe dan venajugularis, payudara tampak simetris, abdomen tidak ada bekas operasi, terdapat massa pada kiri bawah perut ibu dan adanya nyeri tekan, genetalia tampak lembab tidak ada oedema dan nyeri tekan. Dan pada pemeriksaan laboratorium $\mathrm{Hb} 8,9 \mathrm{~g} / \mathrm{dl}$ dan hasil USG tampak uterus membesar, kontur abnormal dengan gambaran massa lobulated pada adnexa kiri tampak massa kistik, ukuran $\pm 5 \times 6,5 \mathrm{~cm}$, tidak ada cairan bebas.

Pada langkah ini beberapa data menunjukkan situasi emergensi, di mana bidan perlu bertindak segera demi keselamatan ibu. Beberapa data menunjukkan situasi yang memerlukan tindakan segera sementara menunggu instruksi dokter. Tindakan tersebut mungkin juga memerlukan konsultasi dengan tim kesehatan lain. Bidan megevaluasi situasi setiap pasien untuk menentukan asuhan pasien yang paling tepat. Langkah ini mencerminkan kesinambungan dari proses manajemen kebidanan (Nurhayati dkk, 2013: 143). 
Tindakan segera dan kolaborasi dilakukan berdasarkan indikasi yang memerlukan penanganan cepat dan tepat sehingga memerlukan kolaborasi dengan tenaga kesehatan yang ahli di bidangnya, dalam kasus ini, tidak ada indikasi untuk dilakukannya tindakan segera. Akan tetapi, kolaborasi dengan dokter ahli kandungan dilakukan untuk menetapkan diagnosa dengan pemeriksaan USG, pemeriksaan laboratorium dan rencana operasi.

Adanya nyeri perut dan keluarnya darah yang banyak dari jalan lahir disertai dengan gumpalan-gumpalan dapat menyebabkan infeksi apabila tidak ditangani dengan segera. Melakukan kolaborasi dengan dokter untuk tindakan selanjutnya yaitu penatalaksanaan pemberian cairan infus RL, rencana operasi pada tanggal 6 februari 2019 dan penatalaksanaan pemberian obat.

Pada Ny"S" dilakukan tindakan dengan pemasangan infus dengan cairan RL dengan 28 tetes/menit, rencana operasi pada tanggal 6 februari 2019 pukul 09:30 wita, dan penatalaksanaan pemberian obat injeksi cefotaxime/ $12 \mathrm{jam} / \mathrm{IV}$, asam Tranexamat/8 jam/IV, ketorolac 1amp/8jam/IV, ranitidin 1amp/8Jam/IV.

Observasi tanda-tanda vital, kaji adanya tanda infeksi dan anemia, memberikan health education, mendiskusikan pada ibu dan keluarga tentang perencnaan operasi, menjelaskan pada ibu pentingnya dilakukan operasi untuk pengangkatan mioma submukosa dan jika klien setuju maka akan dilakukan tindakan operasi pada tanggal 6 februari 2019, pukul 09:30 wita, memberikan dukungan psikologis dan spiritual, menjelaskan kepada ibu untuk sabar dan berdoa kepada Allah SWT, agar diberi kelancaran operasi dalam pengangkatan mioma submukosa serta melakukan persiapan pelaksanaan tindakan operasi.

Rencana asuhan kebidanan selanjutnya yaitu melakukan pemantauan selama dirawat di rumah sakit untuk memantau keadaan klien apakah nyeri perut dan pengeluaran darahnya berhenti atau tidak. Rencana asuhan yang diberikan yaitu memantau tanda-tanda vital, memberikan Health education yaitu menganjurkan ibu menjaga kebersihan dan mengomsumsi makanan yang bergizi, menjelaskan teknik relaksasi bila timbul nyeri, mengingatkan pada ibu untuk teratur mengomsumsi obatnya.

Pada studi kasus Ny"S" dengan mioma submukosa, semua tindakan yang telah direncanakan seperti penanganan nyeri dan pencegahan pengeluaran darah dari jalan lahir yaitu tindakan pertama adalah memberikan cairan infus RL, memberikan obat analgetik, asam tranexamat $1 \mathrm{amp} / 8 \mathrm{jam} / \mathrm{IV}$, ketorolac $1 \mathrm{amp} / 8 \mathrm{jam} / \mathrm{IV}$, ranitidin $1 \mathrm{amp} / 8 \mathrm{jam} / \mathrm{IV}$, dexametazone $1 \mathrm{amp} / 12 \mathrm{jam} / \mathrm{IV}$. dilakukan tindakan operasi dan ibu setuju, operasi dilakukan 
pada tanggal 6 februari 2019, pukul 09:30 wita. Dan memberikan dukungan psikologis dan spiritual ibu dan keluarga selama di rumah sakit, dapat dilksanakan dengan baik tampa ada hambatan karena adanya kerjasama dan penerimaan yang baik dari klien serta adanya dukungan dari keluarga dan petugas kesehatan di ruang PNC Di RSUD Syech Yusuf Gowa.

Pada kasus ini Ny "S" usia 47 tahun dengan diagnosa mioma submukosa pada kasus ini, diagnosa mioma submukosa ditegakkan berdasarkan anamnesis, pemeriksaan fisik dan pemeriksaan penunjang. Pelaksanaan asuhan untuk mengatasi masalah yang dialami klien adalah dengan tindakan operasi. Pada kasus Ny"S" dilakukan tindakan dengan operasi.

Pada hari pertama Ny"H" memberikan cairan pada ibu dengan memasang infus RL dengan 28 tetes/menit, memberikan obat analgetik asam tranexamat $1 \mathrm{amp} / 8 \mathrm{jam} / \mathrm{IV}$ ketorolac $1 \mathrm{amp} / 8 \mathrm{jam} / \mathrm{IV}$, ranitidine $1 \mathrm{amp} / 8 \mathrm{jam} / \mathrm{IV}$, dexametazone $1 \mathrm{amp} / 12 \mathrm{jam} / \mathrm{IV}$. ibu mengerti bahwa mioma submukosa harus dilakukan tindakan operasi dan ibu bersedia dioperasi pada tanggal 6 februari 2019, pukul 09:300 wita, ibu berpuasa dan beristrahat sebelum dioperasi, ibu menjaga personl higienenya, melakukan persiapan pelaksanan operasi yaitu persiapan alat, persiapan penolong dan persiapan pasien.

Pada hari kedua stadi kasus Ny"S" mengobservasi tanda-tanda vital, pengeluaran darah masih terjadi, menjelaskan pada ibu penyebab perdarahan dan nyeri perut bagian bawah, memberikan dukungan psikologis dan spiritual ibu dengan menganjurkan pada ibu untuk meminta kepada ibu untuk selalu mengingat Allah SWT, memberikan penyuluhan pada ibu tentang personal hygiene yaitu dengan cara mengganti pembalut setiap kali basa atau setiap 2 jam, istrahat yang cukup yaitu tidur siang +2 jam, tidur malam +8 jam, ibu sudah istrahat tetapi ibu tidak istrahat dengan tenang karena rasa nyeri yang dirasakan dan membuat ibu terganggu, ibu melakukan puasa untuk persiapan operasi, ibu bersedia di operasi.

Pada pukul 09:30 wita mendorong klien ke ruang ok, membawa alat dan status klien, melanjutkan pemberian obat antibiotik cefotaxime 1 gram/12jam/IV, asam tranexamat 1 amp/8jam/IV ketorolac $1 \mathrm{amp} / 8 \mathrm{jam} / \mathrm{IV}$, ranitidine $1 \mathrm{amp} / 8 \mathrm{jam} / \mathrm{IV}$.

Pada hari ketiga yaitu pada tanggal 7 februari 2019 dengan post oprasi hari kedua mengganti cairan infus RL dengan 28 tetes/menit pada pukul 00:00 wita, melanjutkan pemberian obat antibiotik cefotaxime $1 \mathrm{gr} / 12 \mathrm{jam} / \mathrm{IV}$, analgetik asam tranexamat 1 amp/8jam/IV, ranitidine $1 \mathrm{amp} / 8 \mathrm{jam} / \mathrm{IV}$, ketorolac $1 \mathrm{amp} / 8 \mathrm{jam} / \mathrm{IV}$, metrinidazole 0,5gr/8jam/IV. Memantau tanda-tanda vital, keadaan ibu baik ditandai dengan TTV dalam batas normal, walaupun ibu sudah sehat tetap memberikan kongseling tentang health 
education pada ibu yaitu makan makanan yang bergizi seperti nasi, ikan, sayur-sayuran hijau dan buah-buahan, personal hygiene yaitu dengan menjaga kebersihan dirinya terutama daerah genetalia dengan cara sering mengganti pakaian dalam, pembalut setiap 2 jam atau setiap selesai $\mathrm{BAB} / \mathrm{BAK}$, istrahat yang cukup yaitu dengan menganjurkan pada ibu untuk tidur siang +2 jam pada siang hari dan tidur +8 jam pada malam hari. Mengingatkan pada ibu untuk teratur minum obatnya. Setelah dilakukan pembimbingan pada ibu, ibu mengerti dan melakukan apa yang dianjurkan. Pada tanggal 8 februari $2019 \mathrm{Hb}$ ibu 12 gr/dl dan ibu pulang dalam kedaan sehat.

\section{KESIMPULAN DAN SARAN}

\section{A. KESIMPULAN}

1. Dalam melakukan pengumpulan data dasar pada Ny "S" dengan mioma submukosa dilaksanakan dengan mengumpulkan data subjektif yang diperoleh dari hasil wawancara dimana ibu mengatakan mengalami nyeri pada perut bagian bawah dan perut terasa penuh/berat, data objektif diperoleh dari pemeriksaan fisik seperti dilakukan palpasi pada abdomen didapatkan massa/benjolan disertai adanya nyeri tekan. Sedangkan pada pemeriksaan penunjang dilakukan pemeriksaan USG tampak uterus $\mathrm{UK} \pm 5 \times 6,5 \mathrm{~cm}$, kontur abnormal dengan gambaran massa lobhulated pada adnexa sinistra, dengan small mural nodular, cairan bebas tidak ada.

2. Identifikasi diagnose atau masalah aktual dilakukan dengan pengumpulan data secara teliti dan akurat, sehingga didapatkan diagnosa kebidanan pada Ny "S" mioma submukosa dengan nyeri pada bagian bawah perut kiri, terdapat massa/benjolan disertai dengan kecemasan pada ibu.

3. Diagnosa potensial pada kasus ini tidak muncul karena penanganan yang cepat dan tetap

4. Perlunya tindakan segera dan kolaborasi dengan doter SpOG untuk dilakukan tindakan operasi dan pemberian obat-obatan.

5. Telah menetapkan rencana tindakan asuhan kebidanan pada Ny "S" dengn mioma submukosa DI RSUD Syekh Yusuf Gowa Tahun 2019 dengan hasil merencanakan asuhan berdasarkan diagnosa/masalah aktual dan masalah potensial yang dapat terjadi. 
6. Telah melaksanakan tindakan asuhan yang telah direncanakan pada Ny "S" dengan mioma submukosa di RSUD Syekh Yusuf Gowa tahun 2019 dengan hasil yaitu semua tindakan yang telah direncanakan dapat dilaksanakan seluruhnya dengan baik tanpa adanya hambatan.

7. Evaluasi asuhan kebidanan yang diberikan pada Ny "S" dengan mioma submukosa yang memerlukan penanganan sesuai dengan protap yang ada dapat berhasil karena pasien tidak merasakan nyeri perut bagian bawah, tidak ada benjolan dalam perut, dan ibu melakukan aktivitas seperti biasa. Dalam hal ini tidak ada kesenjangan antara teori dan kasus nyata dilapangan

\section{B. SARAN}

Berdasarkan tinjauan kasus dan pembahasan kasus, penulis memberikan sedikit masukan atau saran yang diharapkan dapat bermanfaat.

1. Untuk Klien dan Keluarga

Diharapkan klien dan keluarga mengerti tentang penyakit gangguan reproduksi khususnya mioma submukosa yang dialami oleh klien sehingga dapat membantu perawatan klien selanjutnya setelah pulang ke rumah. Keluarga juga dapat mengetahui tanda dan gejala dari mioma submukosa sehingga dapat mengetahui secara dini apabila menemukan tanda dan gejala dari mioma submukosa tersebut.

a. Menganjurkan kepada ibu agar banyak istirahat

b. Menganjurkan kepada ibu untuk mengkomsumsi makanan dengan gizi seimbang.

c. Menganjurkan kepada ibu untuk mengkomsumsi obat secara teratur sesuai instruksi dokter.

d. Menganjurkan kepada ibu untuk menjaga kebersihan alat genetalianya

e. Menganjurkan kepada ibu untuk mobilisasi dini.

2. Untuk Institusi dan Akdemik

Diharapkan institusi dan akademik dapat membantu dalam penyediaan sarana berupa referensi atau buku sumber tentang gangguan sistem reproduksi khususnya tentang mioma submukosa yang lebih memadai sehingga mempermudah penulis dan 
mahasiswa lainnya dalam mencari bahan rujukan untuk pembuatan karya tulis selanjutnya.

3. Bagi profesi

Meningkatkan mutu pelayanan dan penanganan bagi klien dengan gangguan sistem reproduksi secara cepat, tepat dan komprehensip.

\section{DAFTAR PUSTAKA}

Apriani Yosi, Sumarni Sri. :/jurnal Kebidanan. Faktor - faktor Yang Berhubungan Dengan Kejadian Mioma Uteri Di RSUD dr. Adhyatma Semarang. Diakses tanggal 17 Januari 2017.

Aspiani, Y, R. Buku Ajar Asuhan Keperawatan Maternitas. Jakarta : 2017.

Ahmad Syahlani, Fator-faktor Yang Berhubungan Dengan Kejadian Mioma Uteri, Dinamika Kesehatan, Vol 7 No. 1 Juli 2016.

Amrina Octaviana Pranajaya R.: //Jurnal Keperawatan Usia Dan Paritas dengan Kejadian Mioma Uteri, Volume X, No.2 Oktober 2014.

Chandranita Manuaba Ayu Ida, dkk Ilmu Kebidanan penyakit kandungan dan KB. Jakarta: 2010 .

Dinas Kesehatan Provinsi Sulawesi Selatan, profil kesehatan Provinsi Sulawesi Selatan,2014.

Elgitha Rahayu, dkk. Mioma Geburt Dengan Anemia, Volume.1, Nomor 1, Februari 2019.

Faridasi Firman, Efektivitas Terapi Murottal dan Terapi Musik Klasik Terhadap Penurunan Tingkat Kecemasan Pasien Pra Operasi di Pekalongan, Vol V 2 september 2012.

Hollingworth Tony. Diagnosis Banding Dalam Obstetri \& Ginekologi. Jakarta: 2012.

Irianti Bayu, dkk. Asuhan Kehamilan Berbasis Bukti. Jakarta: C.V. Sagung Seto, 2014.

Jurnal Kesehatan Ibu dan Anak Akademi Kebidanan An-Nur, Volume 1, Nomor 1, Desember, 2016.

Jannah Nurul. Buku Ajar Asuhan Kebidanan-kehamilan. Yogyakarta:C.V ANDI OFFSET, 2012.

Katsir ibnu,dkk. Shahih Tafsir Ibnu Katsir. jilid 5. Jakarta: pustaka Imam Asy-Syafit I, 2003. 
Kementrian Agama RI, Al-Qur'an dan tajwid. Bandung: PT Sigma Examedia Arkanlema. 2015.

Masrizal :/Jurnal Kesehatan Masyarakat Anemia Defisiensi Besi, 2007.

Marmi, dkk, Kesehatan Reproduksi. Celeban Timur: Pustaka Pelajar, 2014.

Manuaba, Penuntun Kepaniteraan Klinik Obstetri dan Ginekologi. Edisi 2 Jakarta, EGC, 2004

Muslim bin al-Hajjāj Abū al-Ḥasan al-Qusyairì an-Naisabūrì, Al-Musnad al-Sahịh alMukhtașir, Juz IV (t.tc; Beirūt: Dār Ihyā al-Turās al-'Arabiyya, 261H), h.1729

Prawihardjo Sarwono, Doktor, dr. prof. Ilmu kandungan. Jakarta: PT Bina Pustaka, 2014.

Pratiwi, Hubungan Usia Reproduksi Dengan Kejadian Mioma Uteri. Volume 1, Nomor 1 Maret, 2013.

Purwodadi:/Jurnal Kesehatan Ibu Dan Anak. Akademi Kebbidanan An - Nur, Volume 1, Nomor 1 Desember, 2016.

Rasjidi, imam, Doktor, dr. Imaging Ginekologi Onkologi. Jakarta: 2010.

Suryasaputra Manuaba, dkk. Buku Ajar Ginekologi. Jakarta: 2010.

Sabrianti pasinggi. Prevalensi Mioma Uteri Berdasarkan Umur Di RSUP Prof. Dr. R.D. Kondou Manado Tahun 2013-2014. Jurnal e-clinic (eCl), (Volume 3, Nomor 1 januariApril 2015).

Shihab, M. Quraish, pesan kesan dan keserasian Al-Qur'an, Jakarta, Lentara Hati, 2009.

Salim Anwar Islimsyaf :/ Jurnal Ilmiah Ilmu-Ilmu Kesehatan, Vol 13 No 3, Desember 2015.

Th Endang Purwoastuti. Ilmu Obstetri dan Ginekologi Sosial untuk Kebidanan. Pustaka Baru Press:Yogyakarta: 2015

Tresnawati Frisca. Asuhan Kebidanan. PT. Prestasi Pustakaraya Jakarta: 2013.

Thomason phiilip, Leimyoma uterus (fibroid). http://emidici medscape.com/article. Diakses 15 Maret 2009.

Tony Hollingworth, Diagnosis Banding Dalam Obstetri \& Ginekologi, Jakarta, 2012

Wiley John, Sons 1td, Obsetric \& Ginekologi, Tim Child Associate Professor in Reproductive Medicine University of Oxford, 2017. 